\title{
Effect of either soya or linseed oil supplementation of grazing dairy cows on milk production and methane emissions
}

J D Rowntree ${ }^{1}, K_{\text {M Pierce }}^{1}$, F Buckley ${ }^{3}$, K J Petrie ${ }^{1}$, J J Callan ${ }^{1}$, D A Kenny ${ }^{2}$, T M Boland ${ }^{1}$

${ }^{1}$ University College Dublin, Lyons Research Farm, Newcastle, Co. Dublin, Ireland

${ }^{2}$ Animal Bioscience Centre, Teagasc, Dunsany, Co. Meath, Ireland

${ }^{3}$ Moorepark Dairy Production Research Centre, Teagasc, Moorepark, Fermoy, Co. Cork, Ireland

Email: tommy.boland@ucd.ie

Introduction Methane $\left(\mathrm{CH}_{4}\right)$ accounts for approximately $50 \%$ of total greenhouse gas $\left(\mathrm{GHG}\right.$ ) emissions (on a $\mathrm{CO}_{2}$ equivalents basis) from the average Irish dairy farm and represents a loss of up to $8.5 \%$ of gross energy intake (GEI) in dairy cows (Tamminga et al., 2007). Dietary polyunsaturated fatty acid (PUFA) supplementation, especially linoleic (n-6) and linolenic acids (n-3) have been shown to reduce ruminal methanogensis (Martin et al., 2008, Petrie et al., 2009) in indoor housed animals. The aim of this study was to assess the impact of oils rich in either n-3 or n-6 PUFA on milk production and $\mathrm{CH}_{4}$ emissions of grazing dairy cows.

Materials and methods Forty five Holstein Friesian cows were blocked according to parity (24 multiparous and 21 primiparous) and allocated to one of three dietary treatments balanced for days in milk (mean 143 days, S.D. \pm 22 ) and preexperimental milk yield (mean 24.6 litres, S.D. \pm 4.8 ) in a randomised block design. All treatments were allocated $17 \mathrm{~kg}$ grazed grass DM per day per cow, following morning milking plus $4 \mathrm{~kg}(\mathrm{DM})$ of concentrates containing $160 \mathrm{~g} / \mathrm{kg}(\mathrm{FW})$ of stearic acid (C), soya oil (SO) or linseed oil (LO), daily. Concentrates were offered in equal allocations at morning and afternoon milkings. Animals were introduced to their treatment diets over a 7-day period, following which they had an adjustment period of 17 days. Individual $\mathrm{CH}_{4}$ emissions were measured using the $\mathrm{SF}_{6}$ technique as described by Johnson $e t$ al. (1994), 17 (PI) and 44 (PII) days post diet introduction. Milk production was recorded daily and milk composition was assessed on a weekly basis. Statistical analysis was performed using the mixed procedure of SAS with terms included for treatment, period and their interaction.

Results Data for $\mathrm{CH}_{4}$ emissions are shown in Table 1. Both treatment and period affected all $\mathrm{CH}_{4}$ variables measured $(\mathrm{P}<0.001)$. There were treatment $\mathrm{x}$ period interactions for daily $\mathrm{CH}_{4}(\mathrm{P}<0.001), \mathrm{CH}_{4} / \mathrm{kg}$ milk $(\mathrm{P}<0.01)$ and $\mathrm{CH}_{4} / \mathrm{kg}$ milk solids $(\mathrm{P}<0.001)$. During PI both SO and LO reduced all $\mathrm{CH}_{4}$ variables compared to the control, but during PII only LO reduced $\mathrm{CH}_{4}$ variables compared to the control. Data for milk production across the entire experimental period are presented in Table 2. SO increased milk yield $(\mathrm{P}<0.001)$, milk protein $\%(\mathrm{P}<0.001)$ and milk solids yield $(\mathrm{P}<0.05)$, and reduced milk fat $\%(\mathrm{P}<0.01)$ when compared to $\mathrm{C}$ and increased milk yield compared to $\mathrm{LO}(\mathrm{P}<0.001)$. LO increased milk protein \% $(\mathrm{P}<0.001)$ compared to $\mathrm{C}$ but did not differ from $\mathrm{C}$ for any other milk production variable measured.

Table 1 Effect of supplementary lipid source on methane emissions of grazing dairy cows

\begin{tabular}{lccccccccccc}
\hline \hline & \multicolumn{4}{c}{ Period I } & \multicolumn{4}{c}{ Period II } & \multicolumn{4}{c}{ Significance } \\
\cline { 2 - 11 } & $\mathrm{C}$ & SO & LO & s.e.m & C & SO & LO & s.e.m & T & P & Tx P \\
\hline Daily CH 4 (g) & $260^{\mathrm{a}}$ & $239^{\mathrm{b}}$ & $221^{\mathrm{c}}$ & 7.2 & $331^{\mathrm{a}}$ & $348^{\mathrm{a}}$ & $267^{\mathrm{b}}$ & 7.1 & $* * *$ & $* * *$ & $* * *$ \\
$\mathrm{gCH}_{4} / \mathrm{kg}$ milk & $13.72^{\mathrm{a}}$ & $11.99^{\mathrm{b}}$ & $11.06^{\mathrm{c}}$ & 0.4 & $18.38^{\mathrm{a}}$ & $17.74^{\mathrm{a}}$ & $13.93^{\mathrm{b}}$ & 0.4 & $* * *$ & $* * *$ & $* *$ \\
$\mathrm{gCH}_{4} / \mathrm{kg}$ milk solids & $181.3^{\mathrm{a}}$ & $161.1^{\mathrm{b}}$ & $152.2^{\mathrm{b}}$ & 5.18 & $240.5^{\mathrm{a}}$ & $229.4^{\mathrm{a}}$ & $180.8^{\mathrm{b}}$ & 5.18 & $* * *$ & $* * *$ & $* * *$ \\
\hline \hline
\end{tabular}

${ }^{\mathrm{a}, \mathrm{b}, \mathrm{c}}$ Means with different superscripts within rows are different $* * * \mathrm{P}<0.001 ; * * \mathrm{P}<0.01$

Table 2 Effect of supplementary lipid source on milk production and milk composition of grazing dairy cows

\begin{tabular}{lccccc}
\hline \hline Treatment & Control & Soya oil & Linseed oil & s.e.d & Significance \\
\hline Milk yield $(1 / \mathrm{d})$ & $20.05^{\mathrm{a}}$ & $21.52^{\mathrm{b}}$ & $20.28^{\mathrm{a}}$ & 0.120 & $* * *$ \\
Milk fat \% & $4.18^{\mathrm{a}}$ & $3.84^{\mathrm{b}}$ & $3.96^{\mathrm{ab}}$ & 0.068 & $* *$ \\
Milk protein \% & $3.35^{\mathrm{a}}$ & $3.46^{\mathrm{b}}$ & $3.42^{\mathrm{b}}$ & 0.015 & $* * *$ \\
Milk solids yield $(\mathrm{kg} / \mathrm{d})$ & $1.53^{\mathrm{a}}$ & $1.59^{\mathrm{b}}$ & $1.54^{\mathrm{ab}}$ & 0.018 & $*$ \\
\hline \hline
\end{tabular}

${ }^{a, b, c}$ Means with different superscripts within rows are different $* * * \mathrm{P}<0.001 ; * * \mathrm{P}<0.01 ; * \mathrm{P}<0.05$

Conclusion Both $\mathrm{SO}$ and $\mathrm{LO}$ have the potential to reduce enteric $\mathrm{CH}_{4}$ emissions from grazing dairy cows. However, the effects of LO appear to have a greater persistency over time. Furthermore, the addition of PUFA maintained or enhanced milk production variables compared to a saturated fat supplement.

Acknowledgements Funding for this research was provided under the National Development Plan, through the Research Stimulus Fund, administered by the Department of Agriculture, Fisheries \& Food, Ireland.

\section{References}

Johnson, K., Huyler, M., Westburg, H., Lamb, B. and Zimmerman, P. 1994. Environmental Science and Technology 28, $359-362$. Petrie, K J., Hart, K.J., Callan, J., Boland, T.M. and Kenny, D.A. 2009. Proceedings of the British Society of Animal Science, 25.

Martin, C., Rouel, J., Jouany, J.P, Doreau, M. and Chilliard, Y. 2008. Journal of Animal Science 86, 2642-2650.

Tamminga, S., Bannik, A., Dijkstra, J. and Zom, D. 2007. Animal Sciences Group Wageningen University, Report 34. 